\title{
Usefulness and applicability of web-based headache diagnostic software
}

\author{
A Radojicic $^{1 *}$, M Nikolic ${ }^{2}$, J Zidverc-Trajkovic ${ }^{1}$, A Podgorac ${ }^{1}$, N Sternic ${ }^{1}$ \\ From The European Headache and Migraine Trust International Congress \\ London, UK. 20-23 September 2012
}

\section{Introduction}

Headache diagnostic software (HDS), developed by Headache center, Neurology Clinic in Belgrade integrates a diagnostic expert system able to suggest the correct ICHD-II diagnosis once all clinical characteristics of a patient's headache have been collected.

Purpose The aim of this pilot study was to test its diagnostic accuracy, the usefulness and applicability in the diagnosis of primary headache disorders and medication overuse headache $(\mathrm{MOH})$.

\section{Methods}

Forty patients with clinical diagnosis of migraine, tension type headache (TTH), cluster headache and $\mathrm{MOH}$ with an Internet access agreed to fill the web-based headache diary 4-6 weeks after their first consultation in Headache center. This diagnostic diary is developed exclusively based on the ICHD-II criteria, and represents the core of HDS. We analyzed the level of agreement between diagnosis given after clinical interview and obtained by HDS as well as patients' level of compliance.

\section{Results}

Patients' understanding of the diary proved highly satisfactory which was followed by good compliance (77.5\%). Number of patients with one headache diagnosis was 22; 9 patients received 2 or 3 different diagnosis. All patients with a clinical diagnosis of migraine (21) had at least one migraine attack recognized by HDS; episodic TTH was less frequent diagnosed using standard clinical interview than by DHS. In all $\mathrm{MOH}$ (4) and cluster headache patients (3) there was complete concordance between clinical and software generated diagnosis.

${ }^{1}$ Headache Center, Neurology Clinic, Clinical Center of Serbia, Serbia and Montenegro

Full list of author information is available at the end of the article

\section{Conclusions}

Web-based HDS can be considered as advanced, userfriendly, useful and reliable diagnostic tool in headache center.

\section{Author details}

${ }^{1}$ Headache Center, Neurology Clinic, Clinical Center of Serbia, Serbia and Montenegro. ${ }^{2}$ Faculty of Mathematics, University of Belgrade, Serbia, Serbia and Montenegro.

Published: 21 February 2013

References

1. Headache Classification Subcommittee of the International Headache Society: The International Classification of Headache Disorders. Cephalalgia , 2 2004, 24(suppl. 1).

2. Maizels M, Wolfe WJ: An expert system for headache diagnosis: the Computerized Headache Assessment tool (CHAT). Headache 2008, 48(1):72-8.

doi:10.1186/1129-2377-14-S1-P142

Cite this article as: Radojicic et al:: Usefulness and applicability of webbased headache diagnostic software. The Journal of Headache and Pain 2013 14(Suppl 1):P142.

\section{SpringerOpen ${ }^{\odot}$}

(C) 2013 Radojicic et al; licensee Springer. This is an Open Access article distributed under the terms of the Creative Commons Attribution License (http://creativecommons.org/licenses/by/2.0), which permits unrestricted use, distribution, and reproduction in any medium, provided the original work is properly cited.
Submit your manuscript to a SpringerOpen ${ }^{\circ}$ journal and benefit from:

- Convenient online submission

- Rigorous peer review

- Immediate publication on acceptance

- Open access: articles freely available online

- High visibility within the field

- Retaining the copyright to your article

Submit your next manuscript at $>$ springeropen.com 